\title{
Lumen
}

Selected Proceedings from the Canadian Society for Eighteenth-Century Studies

\section{“Seven Years of Musical War” (1757-1763) at the German Court of Anhalt-Zerbst}

\section{Barbara M. Reul}

Volume 30, 2011

URI : https://id.erudit.org/iderudit/1007720ar

DOI : https://doi.org/10.7202/1007720ar

Aller au sommaire du numéro

Éditeur(s)

Canadian Society for Eighteenth-Century Studies / Société canadienne d'étude du dix-huitième siècle

ISSN

1209-3696 (imprimé)

1927-8284 (numérique)

Découvrir la revue

Citer cet article

Reul, B. M. (2011). "Seven Years of Musical War" (1757-1763) at the German Court of Anhalt-Zerbst. Lumen, 30, 131-151. https://doi.org/10.7202/1007720ar

Copyright (c) Canadian Society for Eighteenth-Century Studies / Sociéte canadienne d'étude du dix-huitième siècle, 2011
Ce document est protégé par la loi sur le droit d'auteur. L'utilisation des services d'Érudit (y compris la reproduction) est assujettie à sa politique d'utilisation que vous pouvez consulter en ligne.

https://apropos.erudit.org/fr/usagers/politique-dutilisation/ 


\section{9. "Seven Years of Musical War" (1757-1763) at the German Court of Anhalt-Zerbst}

Considering the great impact of the last of the Silesian Wars (the Seven Years War) on the political landscape of the eighteenth century, comparatively little attention has been paid to the question of how it affected musicians serving at German courts. When their rulers left for battle (or exile), instrumentalists and vocalists serving in larger centres such as Berlin and Dresden, for example, experienced discontinued patronage and a clear shift in artistic priorities - away from grand musical productions such as operas toward more intimate performances in private circles. ${ }^{1}$

But what about smaller courts such as the principality of AnhaltZerbst, which boasted not only powerful political connections Catherine the Great, Empress of Russia, was a former princess of Anhalt-Zerbst - but also a vibrant musical life? The latter had been shaped significantly and with great success by Johann Friedrich Fasch (1722-1758), who served as the court's Kapellmeister for over thirty-six years from 1722 until his death in December 1758. His successor was Johann Georg Röllig (1710-1790), court organist, cellist and composer at the court of Anhalt-Zerbst since 1737. When their employer, Friedrich August (1734-1793), the ruling Prince and brother of Catherine the Great, was forced into exile by King Frederick II in Prussia in April 1758 , never to return, the lives of these two directors of music and their musicians changed forever. Röllig, acting Kapellmeister from December 1758 on, was forced to watch his beautiful ensemble, which comprised

1 See the chapters "The Court of Brandenburg-Prussia" (Mary Oleskiewicz) and "The Court of Saxony-Dresden" (Janice B. Stockig) in Music at German Courts, 1715-60: Changing Artistic Priorities, eds. Samantha Owens, Barbara M. Reul and Janice B. Stockigt (Woodbridge: Boydell \& Brewer, 2011). 
professionally trained vocalists as well as string, woodwind, and keyboard players, crumble in front of him. Yet, Röllig's salary virtually doubled between 1762 and 1764 when the court paid him handsomely for composing new, tailor-made works, specifically a new collection of sacred vocal pieces, for the few musicians who were left at his disposal. At the same time, the court failed to appoint him as the official director of music until $1777 .^{2}$

This article describes for the first time in detail the impact of the Seven Years' War on musical life at the court of Anhalt-Zerbst over the course of seven years, between 1757 and 1763. Little-known archival sources held at the Landeshauptarchiv Sachsen-Anhalt in Dessau, Germany, will be examined to track the gradual demise of the Kapelle in each of these seven "years of musical war". This allows us to appreciate more fully how court officials and music directors coped with reduced performing forces, unsuitable repertoire, and a lack of financial support for the fine arts in general.

\section{Year 1 - 1757: Beglückter Tag (Joyous Day) ${ }^{3}$}

We are fortunate to have extant in Dessau multiple volumes that describe all activities, including musical performances, at the AnhaltZerbst court chapel between 1719 and 1773. ${ }^{4}$ Fasch's Kapelle performed at least three times a week (for Vespers on Saturdays, as well as during morning and afternoon services on Sundays) throughout the year, a performance schedule that was maintained throughout 1757 . Moreover, the musicians concertized several times a week at the palace and presented special music on birthdays celebrated by members of the princely family - whether the individual honoured was in town or not. On Sunday, 8 May 1757, for instance, the anniversary of Arch-

2 For a general overview of musical life at the court of Anhalt-Zerbst during the first half of the eighteenth century, see Barbara M. Reul, "The Court of Anhalt-Zerbst," in Music at German Courts, 259-86.

3 Unless otherwise indicated, all translations are the present author's.

4 Landeshauptarchiv Sachsen-Anhalt, Abteilung Dessau (hereafter: D-LHASA, DE), Z 93, Konsistorium Zerbst, vols. 351-77. These sources are described more fully in Barbara M. Reul, "Musical-liturgical activities at the Anhalt-Zerbst Court Chapel from 1722 to 1758: the Konsistorium-Zerbst Rep. 15A IX a primary source at the Landesarchiv Oranienbaum," in Johann Friedrich Fasch und sein Wirken für Zerbst, ed. Internationale Fasch-Gesellschaft e.V. [Konstanze Musketa and Barbara Reul], Fasch-Studien 6 (Dessau: Anhaltische Verlagsgesellschaft, 1997), 59-70. 
Duchess Catherine of Russia's birth (actually on 2 May) was celebrated at the court. On that occasion, two newly-composed works were premiered. These included a church cantata with sacred text at the court chapel in the morning, and a secular "serenata" - a multi-sectional work that typically featured several solo vocalists singing melodious arias alternating with more speech-like recitative sections and usually ending with a chorus - at the palace in the evening. ${ }^{5}$

As to the number of musicians would have performed these works under Kapellmeister Fasch's direction, Friedrich Wilhelm Marpurg's Historical-Critical Contributions on Music published that same year, indicates that there were nineteen professional musicians employed at the court: four vocalists and nine musicians playing string instruments (see Table 1). ${ }^{6}$ Curiously, five of the violinists were trumpeters in real life and one was the resident kettle-drummer, while one of the vocalists served as the sexton at a local church. But proficiency on more than one instrument and pursuing two careers were not at all unusual for eighteenth-century German court musicians. ${ }^{7}$ Missing in Marpurg's overview are the junior members of the orchestra, namely, four male choral scholars ("Choralknaben") as well as the oboe- (and possibly violin-) playing members of the palace guard, the Hautboisten. This brings the total number of performing musicians at Anhalt-Zerbst to (at least) twenty-four in 1757, numbers that compare favourably to orchestras at other, similarly sized German courts. ${ }^{9}$ Unique to Zerbst may have been that local grammar school students helped out on special occasions,

5 Barbara M. Reul, "Catherine the Great and the Role of Celebratory Music at the Court of Anhalt-Zerbst," Eighteenth-Century Music 3/2 (2006): 269-309, at 300-02, especially Table 3. It details the church cantatas presented in Catherine's honour at the court chapel from 1746-1773, even though she never set foot on Zerbst soil again after her departure for Russia in 1744.

6 Friedrich Wilhelm Marpurg, Historisch-kritische Beyträge zur Aufnahme der Musik, vol. 3, "2. Stück" (Berlin, 1757), 130-33, see <http://commons.wikimedia.org/ wiki/File:Historisch-Kritische_Beytr\%C3\%A4ge_zur_Aufnahme_der_Musik_ Bd.3.pdf $>$.

7 See Samantha Owens and Barbara M. Reul, “'Das gantze Corpus derer ... musicirenden Personen': An Introduction to German Hofkapellen," in Music at German Courts, 1750-1760, 1-14.

8 See Table 1 below: only musicians who performed inside the palace were listed on pay rolls in the court account books; others (such as court trumpeters, kettledrummers and Hautboisten) were not.

9 See the respective chapters and tables on Anhalt-Zerbst, Gotha and Sondershausen in Music at German Courts. 
such as feast days during the church year and princely birthdays and weddings, including celebrations for Fasch's son Carl Friedrich Christian Fasch (1736-1800), the future founder of the famous Berlin choral society, the "Sing-Akademie". ${ }^{10}$

In 1757, Fasch set to music a serenata text for Catherine's birthday. The text was probably written by the sexton at the local St. Bartholomew Church, Johann Jacob Ulisch, who had been supplying musical poetry since 1751 and also assisted as bass vocalist in the court chapel from 1754 to $1756 .{ }^{11}$ In the fourth movement of Beglückter Tag, the author paid tribute to the reigning Russian Empress Elisabeth, Catherine's motherin-law, even though political super power Prussia, which was watching Anhalt-Zerbst and its Russian connections carefully, considered her its arch enemy [see Figure 1]. ${ }^{12}$ While it is possible that the serenata text was authored prior to the onset of the Seven Years War in 1756, it seems more likely that it was meant as an incentive for Catherine to protect the principality of Anhalt-Zerbst during her brother's reign, given that she occasionally received copies of music in Russia. ${ }^{13}$

10 In a letter to the court penned in March 1754, the elder Fasch himself refers to Carl Fasch's unpaid involvement in the Kapelle during the wedding festivities of Prince Friedrich August and Princess Caroline Wilhelmine, which took place in November 1753. See Barbara M. Reul "Forgive us our debts' - Viewing the life and career of Johann Friedrich Fasch (1688-1758) through the lens of finance," Eighteenth-Century Music 8/2 (2011): 272.

11 D-LHASA, DE, Z 92, Kammer Zerbst, Kammerrechnungen (court account books) $1756 / 57$, p. 273 , nos. 1593-96. J. J. Ulisch had also written the text for a wedding serenata on the occasion of Catherine's nuptials in 1745, set to music by Fasch; see Reul, "Catherine the Great," 285-87.

12 The serenata, scored for soprano, alto, tenor and bass, solo trumpet, two oboes d'amore, two oboes, two flutes, two violins, viola, two bassoons, violone (a type of double bass) and harpsichord, forms part of the library of the Sing-Akademie zu Berlin. The library collection was taken to the Ukraine during World War II and returned to the German State Library Berlin only in 2001 (D-B, shelf mark: S. A. 1145/1288). For a discussion of the serenata, see Elena Sawtschenko, "Zwei bisher unbekannte Werke von Johann Friedrich Fasch in dem aus Kiew zurückgegebenen Archiv der Singakademie zu Berlin," in Johann Friedrich Fasch und der Italienische Stil, ed. Internationale Fasch-Gesellschaft e.V. [Konstanze Musketa], Fasch-Studien 9 (Dessau: Anhalt-Edition Dessau, 2003), 230-42.

13 The text for another wedding serenata for Catherine, Auf! Anhalt-Zerbst, berühmter Fürsten-Sitz! (Rise! Anhalt-Zerbst, Famous Princely Residence!), set to music by Röllig in 1745 , survives in Russia, as well as in D-LHASA, DE, Z 88, Facharchiv Zerbst Fach 103 No. 21a. 
Another sign of the continued vitality of the Anhalt-Zerbst music scene in 1757 was the state of the musical instrument collection. Whether the instruments for which the court reimbursed concertmaster Höckh during the 1757/58 fiscal year - a bassoon, an oboe, two hunting horns and a transverse flute - had already been in use in May 1757 , is unclear. ${ }^{14}$ It emphasizes, however, that maintaining and adding to the collection of musical instruments (established at the turn of the eighteenth century by Prince Carl Wilhelm of Anhalt-Zerbst) continued to be a priority at court.

\section{Year 2 - 1758: “Sehr schwere Zeiten" (“Very Hard Times") $)^{15}$}

In February 1758, Friedrich August greatly angered the Prussian king by refusing to deliver a French enemy spy to him. ${ }^{16}$ Within two months, 1,500 of King Frederick's foot-soldiers, including 400 with canons, descended upon the 6,360 inhabitants of Anhalt-Zerbst. This prompted Friedrich August and his mother to leave town on 8 April — so "eilig und heimlich" ("quickly and in secret"), that his wife, Princess Caroline Wilhelmine (1732-1759), was left behind and told by a privy councilor that her husband and mother-in-law expected her to fend for herself while they waited out the war in Paris. ${ }^{17}$

On the musical front, Fasch's son Carl, harpsichordist to the Prussian king in war-torn Berlin since 1756, returned home for an extended visit in the summer and fall of 1758 . He brought with him none other than his colleague Carl Philipp Emanuel Bach (1714-1788), the famous son of J.S. Bach (1685-1750). As long-time accompanist to and composer for Frederick the Great, C. P. E. Bach was intimately connected with

14 D-LHASA, DE, Z 92, Kammer Zerbst, Kammerrechnungen 1757/58, 291, nos. 2729-31. As dates are not given, it is impossible to determine whether these were purchased in the latter half of 1757 or the first half of 1758 . The fiscal year at the court covered the period 24 June to 23 June.

15 Friedrich Wilhelm Sintenis, Die Chronik von Zerbst 1758-1830, ed. Hannelore Seidler (Zerbst: Verlagsbuchhandlung Friedrich Gast Zerbst and Anhaltische Verlagsgesellschaft Dessau, 1995), 13.

16 Sintenis, Die Chronik von Zerbst, 13-14. A detailed account of the encounter between the Prince and the French spy is presented by Franz Kindscher, "Marquis de Fraigne," in Mitteilungen des Vereins für Anhaltische Geschichte und Altertumskunde 9 (1904): 203-17.

17 Sintenis, Die Chronik von Zerbst, 14. Friedrich August soon moved on from Paris to Prague and Vienna. 
one of the most powerful and musically accomplished members of German royalty of the eighteenth century. ${ }^{18}$ During his visit in Zerbst, Bach wrote a set of sonatas and gave private lessons to Georg Peter Weimar, the newest Kapelle recruit. ${ }^{19}$ Whether Bach assisted with the court Kapelle as well is unclear, but he did not seem to mind providing his expertise as an adjudicator. According to an extant report by the highest-ranking clergy at the palace, the Reverend Dr. Johann Daniel Kluge, a "berühmter Tonkünstler aus Berlin" ("a famous composer from Berlin") was present at the auditions in September 1758 for the vacant organist's position at the former court and colleagiate church, St. Bartholomew. ${ }^{20}$

The visitors from Berlin returned home just days before their employer signaled to Catherine's German relatives that he was going to make the lives of their subjects difficult for years to come. On 4 December 1758 , no fewer than 16,000 Prussian artillery soldiers besieged Zerbst; they wreaked havoc for three days and then left, 30,000 florins richer. ${ }^{21}$ On 7 December, the Prussian General von Wedell gave "the town" (really the Privy Council, a motley crew of court officials who carried out Prince Friedrich August's orders from exile) an ultimatum. Unless 100,000 florins, 800 recruits and 811 horses were supplied to him and his 600 men by 18 December, the town would face the "härteste militärische Exekution" ("hardest [form] of military execution"). The Privy Council complied, with a frightened Princes Caroline Wilhelmine, whose sister had married into the Prussian royal family, asking Frederick II for leniency. He replied that her husband had forced him to take this kind of action. ${ }^{22}$

18 The king was an expert flautist and composer; see E. Eugene Helm and Derek McCulloch, "Frederick II, King of Prussia," in Grove Music Online, Oxford Music Online, <http:/ / www.oxfordmusiconline.com> (accessed June 20, 2011).

19 See David Schulenberg, "C. P. E. Bach in Zerbst: The Six Sonatas of Fall 1758. With Contributions on the Early Biography and Compositions of Carl Fasch," in Johann Friedrich Fasch als Instrumentalkomponist, 131-52. On Weimar, see Barbara M. Reul, "Court Musicians at Anhalt-Zerbst: New Sources for Eighteenth-Century Employment Practices," Haydn and his Contemporaries, ed. Sterling Murray (Ann Arbor, Michigan: Steglein, 2011), 117-52, esp. 132 and 134.

20 D-LHASA, DE, Z 93, Konsistorium Zerbst, No. 275, fol. 20r. Curiously, the other adjudicators - court organist Röllig and concertmaster Höckh who had replaced an ailing Kapellmeister Fasch — failed to mention Bach's presence.

21 Sintenis, Die Chronik von Zerbst,14, notes that the officer in charge, Count von Dohna, also took with him seventy horses and many head of cattle. 
These events overshadowed the death of Kapellmeister Fasch on 5 December 1758 at the age of seventy. Two months earlier, Fasch had prepared an overview of the music and musical instruments owned by the court, in the form of an update (albeit with considerably less attention to detail) to an inventory made in $1743 .{ }^{23}$ Musical priorities had definitely shifted at the palace: rather than acquiring or writing works that showcased the abilities of individual players, Fasch opted for compositions that emphasized the skills of the entire ensemble instead. In particular, the number of "Sinfonias" and so-called "Quadro Sonatas" (the latter involving three competing soloists accompanied by a keyboard/low string or woodwind group of players known as the Basso continuo) had increased substantially, from twenty-eight to 140 compositions. ${ }^{24}$ Both musical genres are predecessors of the symphony, which in the hands of Haydn, Mozart, and Beethoven would revolutionize music in the Classical style during the second half of the eighteenth century. This interest in the Sinfonia and Quadro Sonata genres underscores the fact that Fasch, who exchanged music with the electoral court of Dresden for over twenty-five years, was keenly aware of popular musical trends. ${ }^{25}$

\section{Year 3-1759: Business as usual}

Despite the large payments made to Prussian army officers in late 1758, the Anhalt-Zerbst Kapelle was not immediately affected by spending

23 This is discussed in detail in Barbara M. Reul, "Musical Life at the Court of AnhaltZerbst: An Examination of Unknown Primary Sources at the Landeshauptarchiv Sachsen-Anhalt, Abteilung Dessau," in Musik an der Zerbster Residenz, eds. Stadt Zerbst/Anhalt and Internationale Fasch-Gesellschaft e. V. Zerbst [Konstanze Musketa and Barbara M. Reul], Fasch-Studien 10 (Beeskow: ortus-Verlag, 2008), 210-18. See also the Concert-Stube des Zerbster Schlosses, Inventarverzeichnis aufgestellt im März 1743, published as vol. 4 of Studien zur Aufführungspraxis und Interpretation der Musik des 18. Jahrhunderts: Dokumentationen/Reprints, ed. Eitelfriedrich Thom (Michaelstein/Blankenburg: [no publisher], 1983).

24 Unlike the 1743 inventory, Fasch did not list compositions individually but grouped them together by genre. Therefore, it is unclear how many of these works Fasch had composed and how many he had acquired elsewhere. Höckh and Röllig, for example, could have provided him with copies of their Sinfonias and other works.

25 Suzanne G. Cusick and Jan Larue, "Sinfonia," and Jan Larue et al., "Symphony," in Grove Music Online. Oxford Music Online, <http://www.oxfordmusiconline. com>(accessed May 10, 2011). On Fasch's exchange of music with Dresden and other German courts, see Reul, "Catherine the Great," 273-77. 
cuts, and performances at the court chapel continued throughout 1759. Since concertmaster Höckh and J. G. Röllig were sharing Kapellmeister duties, we cannot be sure whether the court was actively looking to replace Fasch. ${ }^{26}$ In 1777, J. G. Röllig recalled that he was "acting" Kapellmeister in 1759, meaning he would have composed music for the court. Extant account books confirm, however, only his status as organist and chamber musician. ${ }^{27}$ Furthermore, Johann Wilhelm Hertel (1727-1789), a former student of concertmaster Höckh and Kapellmeister of Mecklenburg-Schwerin, composed a birthday serenata in honour of Princess Caroline Wilhelmine in 1759. As a keyboard student of Röllig, who owned music by C. P. E. Bach, Hertel may have been personally encouraged by the princess to apply for the position of Kapellmeister. ${ }^{28}$ In the end, it would not have mattered, for the princess possessed no political power and, sadly, passed away before she could have facilitated an appointment. Her death on 22 May 1759 also meant that for the first time ever during the eighteenth century, the palace did not house a member of the princely family, especially one who appreciated musical entertainment provided by the Kapelle. But perhaps Friedrich August or his mother, or both, were going to return from exile soon?

\section{Year 4-1760: Annus horribilis (Year of Horror)}

Since the Prussian king continued to put pressure on the Anhalt-Zerbst court in 1760, coming home was not a viable option for the widowed prince, at least not yet. ${ }^{29}$ Instead, Friedrich August approved desperate measures to decrease the court's operating budget, including that of the Kapelle. When oboist Ritter and soprano Kettner died in 1760, they were

26 Performances of sacred music during the church year $1758 / 59$ are detailed in D-LHASA, DE, Z 93, Konsistorium Zerbst, IXa, vol. 363; entries that document Kapelle-related payments appear in Z 92, Kammer Zerbst, Kammerrechnungen 1758/59, 233, no. 2385 (Höckh) and — belatedly — in 1762/63, 245, no. 19.2004 (Röllig).

27 On Röllig, see Nigel Springthorpe, "Who was Röllig? - Röllig and the Sing-Akademie Collection", in Musik an der Zerbster Residenz, 117-40, and Reul, "The Court of Anhalt-Zerbst," 268.

28 Hertel's Serenata and the events surrounding Caroline Wilhelmine's passing are discussed in Brian Clark, "Eine kleine Nachtmusik," in Musik an der Zerbster Residenz, 281-93.

29 Sintenis, Die Chronik von Zerbst, 16-18, detail the King's demands, including 100,000 florins cash, 240 additional recruits and 300 horses in January 1760 alone. 
not replaced, and four more musicians (two vocalists, an oboist and a bassoonist) were dismissed altogether. ${ }^{30}$ For the Kapelle, this meant that it would be difficult to perform any of the large-scale music in its repertoire, owing to lack of forces. In the same year, the court reimbursed only the poet, Ulisch, and not Röllig for supplying texts for princely birthday cantatas and serenatas. Why this was so is unclear. ${ }^{31}$ Had Röllig perhaps volunteered his services? In any event, he was paid for the special music he had composed between 6 May 1759 and 25 December 1760 , but not until $1763 .^{32}$ Since none of these works seem to have survived, it is difficult to determine whether and how Röllig had modified his compositional approach to provide music that his ensemble could actually perform.

The annus horribilis was also marked by the death of Catherine's mother, Johanna Elisabeth, on 22 May 1760. The Dowager Princess had, according to Friedrich Wilhelm Sintenis, "lived in Paris as Countess von Oldenburg with great extravagance, consumed the majority of the principality's income [and received] a pension of 15,000 rubles from Russia." ${ }^{33}$ News of her death reached Anhalt-Zerbst on 11 June, but it took until 18 December to move her remains and bury them in what is now the vault of St. Bartholomew Collegiate Church in Zerbst. Interestingly, the four musicians who had been dismissed earlier that year were asked to help out at the "Trauer Begräbnis," a memorial service organized by the court for Johanna Elisabeth, but they were paid only half of what their colleagues received. ${ }^{34}$ Meanwhile, Prussian soldiers continued to keep the town of Zerbst in check, especially with regard to their impressment of recruits: "wo ein tauglicher Mann von ihnen auf

30 See the payroll entries in D-LHASA, DE, Z 92, Kammer Zerbst, Kammerrechnungen $1760 / 61,109$. Eighteen other court employees, including individuals not residing in Zerbst, were released as well, resulting in savings of over 2,000 florins in yearly salaries (see the archival documents contained in Kammer Zerbst, No. 2975). Several court employees appealed the decision, albeit unsuccessfully.

31 D-LHASA, DE, Z 92, Kammer Zerbst, Kammerrechnungen 1760/61, 215, nos. 6.1496 and 45.1797 .

32 D-LHASA, DE, Z 92, Kammer Zerbst, Kammerrechnungen 1762/63, 245, no. 19.2004 (Röllig).

33 Sintenis, Die Chronik von Zerbst, 17: "Sie lebte dort als Gräfin von Oldenburg mit vielem Aufwande, verzehrte den größten Teil der Landeseinkünfte, sowie eine Pension von 15000 Rubeln, welche sie von seiten Rußlands bezog."

34 D-LHASA, DE, Z 92, Kammer Zerbst, Kammerrechnungen 1760/61, 243, nos. 1781-85. 
der Straße bemerkt wird, so greifen sie ihn auf" ("when they spotted a suitable male on the street, they grabbed him"). ${ }^{35}$

\section{Years 5 and $6-1761$ and 1762: Coping strategies}

Despite the fact that the Kapelle membership had been decimated in the fall of 1760, regular performances at the palace continued, because Röllig immediately enlisted the help of junior musicians and retired colleagues. It is also conceivable that musically gifted students at the St. Bartholomew School volunteered their services. Christian Ernst Kallenbach, for example, had previously substituted for an ailing Röllig in $1758 .{ }^{36}$ With regard to musical repertoire presented at the court chapel in the early 1760s, Röllig turned to a collection of sacred works known as the "Sicilian" cantata cycle by one of the most famous German composers at the time, Georg Philipp Telemann (1681-1767), civic music director of Hamburg. ${ }^{37}$ Samuel Gottlieb Poll's son, Friedrich Christian, seems to have begun participating regularly with the Kapelle in the fall of 1760. In addition to worship services on Sundays and feast days, he would have performed during Holy Week in 1761 which featured a new "Paßions-Musique" (a setting of one of the four Gospel Passions) by Röllig. ${ }^{38}$ But young Poll never received a penny (or in this case Kreutzer) for his many hours of diligent service. At least that was what his father emphasized in a hitherto-unknown letter to Zerbst court officials written on 23 March 1762, ten days prior to Holy Week, one of the busiest period of the church year. Apparently, Friedrich Christian was threatening to quit unless the court paid up and provided him "reine Kleidung und Wäsche" (clean clothes and underwear). ${ }^{39}$ Asking the

35 Sintenis, Die Chronik von Zerbst, p. 17. On 4 March 1760, all males between the ages of fifteen and fifty had been asked to report for duty.

36 As mentioned by Kallenbach in his application for the vacant organist's position at St. Bartholomew Church in 1758, see D-LHASA, DE, Z 93, Konsistorium IXa, vol. 275 , fol. 2.

37 Curiously, this cycle of sacred cantatas was performed six times during Fasch's thirty-six-year tenure but does not appear in the contents of the "Concert-Stube". This may have been an oversight of the scribe, who also failed to refer to any music that Fasch, Röllig (and possibly others) had composed for Holy Week.

38 D-LHASA, DE, Z 92, Kammer Zerbst, Kammerrechnungen 1760/61, 215, no. 45.1463 (payment received by Röllig).

39 D-LHASA, DE, Z 88, Facharchiv Zerbst Fach 12 Nr. 9, fol. 70. 
court for financial assistance was now feasible again, for in late February 1762 all Prussian troops had been ordered to leave Zerbst, which they did, "obschon sehr ungern" ("albeit very reluctantly"). was no longer a good reason to occupy Zerbst: Empress Elisabeth of Russia had passed away on 5 January 1762 and her successor, Peter III, Catherine's husband, was an ardent admirer of King Frederick the Great. On 22 February, the Anhalt-Zerbst court had - for the first time ever - acknowledged through music the Emperor's birthday, as well as his successful accession to the Russian throne on 28 February $1762{ }^{41}$ In any case, both Polls must have been pleased when the court paid a douceur (honorarium) of ten florins for " $13 / 4$ jährigen Singens" (one year and nine months of singing) before the end of the fiscal year 1761/62. ${ }^{42}$

But that amount was not sufficient for a Kapellknabe, according to acting Kapellmeister Röllig. On 29 October 1762 he courageously shared his musical vision for the upcoming church year in a hitherto-unknown proposal that details the "Umstände und Beschaffenheit" (circumstances and constitution) of the Kapelle in 1761 and 1762 (see Figure 2). ${ }^{43}$ With only one full-time vocalist on staff (S. G. Poll), Röllig himself partly out of loyalty to his employer, partly because of his "Liebe zur Kirchen musiq" (love of sacred music) - had sung the alto and bass solo parts in works that were performed at the chapel from fall 1760 onward. In addition, the musical repertoire to which he had access was becoming increasingly impracticable because it required bigger orchestral and vocal forces than those he had to hand. Röllig's poor health now forced him to discontinue these "ungewohnte[n] und zur Zeit noch unbelohnte[n] Verrichtungen" (unfamiliar and still unpaid activities). ${ }^{44}$

40 Sintenis, Die Chronik von Zerbst, 19.

41 D-LHASA, DE, Z 92, Kammer Zerbst, Kammerrechnungen 1761/62, 215, no. 36.1462 (payment received by Röllig). A "Magister Natho" — possibly Erdmann Friedrich Natho, "Subdiaconus" at the court chapel and St. Bartholomew Church in 1766, see Konsistorium Zerbst III, no. 8, fol. 148 - was paid for providing the text for Catherine's birthday (Kammerrechnungen 1761/62, 215, no. 47.1467).

42 D-LHASA, DE, Z 92, Kammer Zerbst, Kammerrechnungen 176/62, 215, no. 45.1465. There is no actual date given, but the entries that precede it refer to events in May 1762 (Catherine's birthday).

43 D-LHASA, DE, Z 88, Facharchiv Zerbst Fach 12 Nr. 9, fols. 230-231. All quotations used in this section are taken from this autograph letter.

44 See Reul, "Musical Life at the Court of Anhalt-Zerbst," 204. In 1755 when Röllig had complained to the court about having to step in constantly for ailing or absent members of the Kapelle, he had noted specifically how stressful singing was for 
At the same time he desired musical performances to continue at the chapel, even though an official order from the court had not yet been received.

Röllig's solution to the problem of having not enough musicians and unsuitable repertoire was to compose an entirely new cantata cycle tailored to the skill levels of his Kapelle members. ${ }^{45}$ He envisaged seventy-one cantatas to cover all Sundays and feast days in the church year, including Holy Week, and even princely birthdays. With regard to musical scoring, there would be no more than two vocal parts (rather than the usual four voices). They would be sung by S. G. Poll and his young son, "welcher das beste Talent zur Musiq besitze und als ein Kapellknabe und Sänger sehr wohl zugebrauchen ist" (who possessed the best musical talent [of all] and is very useful as a Kapellknabe and vocalist). Röllig then reminded the court that the sons of the late soprano Christian Carl Kettner had each received twenty-five Thaler a year as Kapellknaben (from 1737 to 1745) and even "ohngefähr 12 Thlr zu einem Kleide" (approximately twelve Thaler for a uniform) during their first year. Finally, with the first Sunday of Advent in late November fast approaching, Röllig asked that his proposition be considered quickly, so he could start composing the new cantata cycle immediately.

And the court did respond: on 9 December 1762, chamberlain Schröter was instructed to pay Röllig a total of 142 florins, including thirty Thaler up front, for the new cantata cycle. In addition, Poll junior would receive thirty-seven florins "Salario" per year which included twelve florins "zu neuem Kleyde" (for a new uniform). ${ }^{46}$

What Röllig had probably not seen coming was that special music at Vespers (evening services that had been celebrated at the court chapel on Saturdays and on days preceding feast days since 1719 when the chapel had been consecrated) were cancelled altogether as of the first Sunday in Advent, 28 November $1762 .{ }^{47}$ Or had he been the one to sug-

him. Who would have played the organ while Röllig was busy performing is unclear, perhaps one of his more advanced organ students.

45 It was customary during the first half of the eighteenth century for composers to create "new" cantata cycles by drawing from several already existing collections. Two such "mix and match" collections had been in use at the court of Anhalt-Zerbst during J. F. Fasch's tenure as Kapellmeister, the so-called "Halle" and "Dresden" cycles; the latter even contains a cantata by J. S. Bach, "Ich hatte viel Bekümmernis" (BWV 23).

46 D-LHASA, DE, Z 88, Facharchiv Zerbst Fach 12 Nr. 9, fols. 232.

47 See the respective entry in D-LHASA, Z 93, Konsistorium Zerbst IXa, vol. 373. 
gest this option to the court in the first place, as it freed up time for him to focus on composing?

\section{Year 7 - 1763: A new musical agenda}

Poll junior officially joined as Kapellknaben as of Christmas 1762 and received a full year's salary, thirty-seven florins, for the six months up to the end of the fiscal year on 23 June 1763, possibly because he had not been paid at all between June and December $1762{ }^{48}$ Two retired Hautboisten (Köppe and Kötteritz, see Table 1 below), as well as an unnamed vocalist from outside of Zerbst, were also financially acknowledged for their assistance on princely birthdays (specifically, those of Prince Friedrich August and Catherine the Great), as well as the latter's accession to the Russian throne in early July $1762{ }^{49}$

Most importantly, Röllig's annual salary of 170 florins almost doubled between June 1762 and June 1764 because he was paid for a great deal of music on a "per-item" basis (see Table 2) rather than receiving the going Anhalt-Zerbst "Kapellmeister rate" of 400 florins.

Payments ranged from eight to eleven florins per work, probably depending on the length of the poetry to be set to music. ${ }^{50}$ Röllig also contributed thirteen cantatas toward an (incomplete?) cycle by a composer named Förster, mostly likely the Rudolstadt Kapellmeister Christoph Förster (1693-1745). This meant that Röllig had been able to keep special music going for another year during two worship services on Sundays.

How did this tale of "seven years of musical war" at the court of Anhalt-Zerbst end? Much to his frustration, Röllig was not promoted to Kapellmeister in 1764; instead, a newly created title "Kapell-Rath"

48 D-LHASA, DE, Z 92, Kammer Zerbst, Kammerrechnungen 1762/63, 110, no. $159 / 60$. The younger Poll appears only once more in the court records. He received a honorarium of eight florins - an unusually high amount - for performing on the occasion of Catherine's birthday in May 1764: see Kammerrechnungen 1763/64, 231, no. 32.1916 .

49 See the respective entries in D-LHASA, DE, Z 92, Kammer Zerbst, Kammerrechnungen, $1762 / 63,226 ; 255$, no. 13.2177, identifies the two retired Hautboisten by name.

50 In comparison, J. S. Bach, Kapellmeister at the court of nearby Köthen, received ten florins for providing a birthday serenata on the occasion of Prince Johann August of Anhalt-Zerbst's birthday in August 1722. 
(comparable to a privy councilor perhaps?) was bestowed upon him in 1765. Röllig considered this honour an insult and said so publically, which promptly got him into trouble with the court. ${ }^{51}$ His strong reaction was, however, to some extent warranted. From 7 December 1765 onward, all regularly scheduled (that is weekly) musical performances at the court chapel were discontinued, and special music was only to be presented during the Christmas, Easter and Pentecost seasons. But the court's decision is understandable, given that Prince Friedrich August had chosen Basel as his permanent home in June $1764 .{ }^{52}$ Henceforth, Röllig and the few musicians at his disposal performed only occasionally at the court chapel and probably participated in annual birthday celebrations at the court as well. In the 1760s, the birthdays of Friedrich August and his new wife, as well as those of Catherine, her children and her grandchildren, continued to be honoured, albeit in absentia. Röllig waited patiently for a further twelve years to become the last Kapellmeister of Anhalt-Zerbst, a position he held until his death in 1790.

\author{
BARBARA M. REUL \\ Luther College, University of Regina
}

51 For a more detailed description of the incident, see Reul, "Musical Life at the Court of Anhalt-Zerbst," 219-21. Röllig admitted to being drunk that night.

52 Sintenis, Die Chronik von Zerbst, 21. On 9 June 1764, Friedrich August had taken his new bride, Princess Friedericke Auguste Sophie, as far as Friedrichholz, a forested area on the outskirts of Zerbst but never entered the city. 


\section{Table 1: Membership of the Anhalt-Zerbst Court Music Establishment in 1757 and $1763^{53}$}

\begin{tabular}{|c|c|c|}
\hline Years & 1757 & 1763 \\
\hline $\begin{array}{l}\text { Numeric } \\
\text { Overview }\end{array}$ & $\begin{array}{l}1 \text { Kapellmeister, } \\
1 \text { concertmaster; } \\
9 \text { vocalists (including four choral } \\
\text { scholars and } 1 \text { doubling as } \\
\text { instrumentalist); } \\
6 \text { instrumentalists; } \\
\text { 1-4 Hautboisten; } \\
\text { at least } 6 \text { trumpeters \& } 1 \text { kettle- } \\
\text { drummer; } \\
2 \text { additional personnel }\end{array}$ & $\begin{array}{l}\text { [1 acting Kapellmeister;] } \\
1 \text { concertmaster; } \\
6 \text { vocalists (including } 1 \\
\text { Kapellknabe and four choral } \\
\text { scholars); } \\
2 \text { instrumentalists; } \\
\text { ? at least } 2 \text { "retired" Hautboisten } \\
\text { at least } 3 \text { trumpeters \& } 1 \text { kettle- } \\
\text { drummer } \\
2 \text { additional personnel }\end{array}$ \\
\hline Kapellmeister & Johann Friedrich Fasch & $\begin{array}{l}\text { [Johann Georg Röllig, } \\
\text { organ, viola da gamba, and } \\
\text { violoncello; also copyist; acting } \\
\text { Kapellmeister }^{54} \text { ] }\end{array}$ \\
\hline Concertmaster & $\begin{array}{l}\text { Carl Höckh (violin; also horn and } \\
\text { oboe) }\end{array}$ & [C.] Höckh \\
\hline \multicolumn{3}{|l|}{ Vocalists } \\
\hline Soprano & $\begin{array}{l}\text { Johann Michael Teicher (also } \\
\text { copyist, dismissed fall 1760) }\end{array}$ & $\begin{array}{l}\text { Kapellknabe Friedrich August } \\
\text { Poll until mid-June } 1763 ?\end{array}$ \\
\hline Alto & $\begin{array}{l}\text { Christian Carl Kettner (also viola } \\
\text { da gamba and Court secretary; } \\
\text { died in 1760) }\end{array}$ & $?$ \\
\hline
\end{tabular}

53 The information provided in this table draws from a variety of sources: 1) Marpurg, Historisch-kritische Beyträge zur Aufnahme der Musik, vol. 3, "2. Stück”, 130-33; 2) archival documents held at: D-LHASA, DE, Z 92, Kammer Zerbst, Kammerrechnungen 1756/57, 109, 1757/58, 111 and 1763/64, 108; and 3) entries in the "Trau-Register" and "Sterberegister" (marriage and death registers, respectively) of the Anhalt-Zerbst court chapel, held at the St. Bartholomäi Parish Archive in Zerbst/Anhalt, Germany.

54 According to Röllig's autobiographical essay from 1777, reproduced in Hermann Wäschke, "Die Zerbster Hofkapelle unter Fasch," Zerbster Jahrbuch 2 (1906): 62. 


\begin{tabular}{|c|c|c|}
\hline Years & 1757 & 1763 \\
\hline Tenor & $\begin{array}{l}\text { Samuel Gottlieb Poll (also } \\
\text { "Inspector" of the local } \\
\text { orphanage) }\end{array}$ & [S. G.] Poll \\
\hline Bass & $\begin{array}{l}\text { Johann Jacob Ulisch (also } \\
\text { sexton at St. Bartholomew } \\
\text { Church, substituting for J. G. } \\
\text { Förster, bass) }\end{array}$ & $?$ \\
\hline Court Cantor & $\begin{array}{l}\text { Michael Gattermann (died in } \\
\text { 1762) }\end{array}$ & $\begin{array}{l}\text { [Duties carried out by } \\
\text { "Hofkirchner" Möhring] }\end{array}$ \\
\hline $\begin{array}{l}\text { Choral Scholars } \\
\text { ("Choralknaben") }\end{array}$ & $\begin{array}{l}\text { Four boys, but names are not } \\
\text { specified }\end{array}$ & $\begin{array}{l}\text { Four boys or fewer, names are not } \\
\text { specified }\end{array}$ \\
\hline \multicolumn{3}{|l|}{ Instrumentalists } \\
\hline \multicolumn{3}{|l|}{$\begin{array}{l}\text { Chamber } \\
\text { Musicians } \\
\text { [performed } \\
\text { also in princely } \\
\text { chambers] }\end{array}$} \\
\hline Violin & $\begin{array}{l}\text { See Concertmaster, Oboe, } \\
\text { Harpsichord, Court Musician, } \\
\text { Court trumpeter, Court Kettle- } \\
\text { Drummer, and "Hofkirchner" }\end{array}$ & $?$ \\
\hline Viola & See Court Musician & ? \\
\hline $\begin{array}{l}\text { Viola da gamba/ } \\
\text { Violoncello }\end{array}$ & $\begin{array}{l}\text { See Alto, Court Organist and } \\
\text { "Hofkirchner" }\end{array}$ & Röllig? \\
\hline $\begin{array}{l}\text { Contraviolone } \\
\text { [Doublebass] }\end{array}$ & Vacant & $?$ \\
\hline Flute/Recorder & See Oboe & $?$ \\
\hline \multirow[t]{2}{*}{ Oboe } & $\begin{array}{l}\text { Johann Georg Fröde (also violin; } \\
\text { flute and recorder?; dismissed } \\
\text { fall 1760) }\end{array}$ & $\begin{array}{l}\text { Two "retired Hautboisten" helped } \\
\text { out at special events }\end{array}$ \\
\hline & $\begin{array}{l}\text { Johann Christoph Ritter (flute } \\
\text { and recorder?; died in 1760); } \\
\text { See Concertmaster }\end{array}$ & \\
\hline
\end{tabular}




\begin{tabular}{|c|c|c|}
\hline Years & 1757 & 1763 \\
\hline Bassoon & $\begin{array}{l}\text { Johann Bernhard Unbescheid } \\
\text { (dismissed September 1760) }\end{array}$ & $?$ \\
\hline Harpsichord & $\begin{array}{l}\text { Christoph Heinicke (also organist } \\
\text { at St. Bartholomew Church, } \\
\text { Zerbst; died in 1758) }\end{array}$ & $\begin{array}{l}\text { Johann Heinrich Heil, } \\
\text { 'Clavicymbalist' (also violin; } \\
\text { appointed organist at St. } \\
\text { Bartholomew Church, Zerbst, in } \\
\text { October 1758, died in 1764) }\end{array}$ \\
\hline Court Organist & $\begin{array}{l}\text { Johann Georg Röllig (also viola } \\
\text { da gamba, violoncello, and } \\
\text { copyist) }\end{array}$ & [J. G.] Röllig \\
\hline $\begin{array}{l}\text { Court Musician } \\
\text { [did not perform } \\
\text { in princely } \\
\text { chambers] }\end{array}$ & $\begin{array}{l}\text { Johann Andreas Vent (died in } \\
\text { 1757); } \\
\text { George Gottlieb Giel (violin? } \\
\text { Viola?; died in 1762) }\end{array}$ & $?$ \\
\hline Kapellknabe $e^{55}$ & $\begin{array}{l}\text { Friedrich Christian Poll } \\
\text { (Christmas 1761-23 June 1762) }\end{array}$ & $?$ \\
\hline \multicolumn{3}{|l|}{$\begin{array}{l}\text { Non-Kapelle } \\
\text { musicians }\end{array}$} \\
\hline \multirow[t]{5}{*}{ Court Trumpeters } & $\begin{array}{l}\text { Johann Caspar Wülcke } \\
\text { (Marpurg: violin) }\end{array}$ & Still active - died in 1766 \\
\hline & $\begin{array}{l}\text { Friedrich Wilhelm Thieß } \\
\text { (Marpurg: violin) }\end{array}$ & $?$ \\
\hline & $\begin{array}{l}\text { Johann Andreas Gregorius } \\
\text { Fliedner (Marpurg: violin) }\end{array}$ & $?$ \\
\hline & $\begin{array}{l}\text { Christian August Nicolai } \\
\text { (Marpurg: violin) }\end{array}$ & $?$ \\
\hline & $\begin{array}{l}\text { Gottfried Rühlmann (Marpurg: } \\
\text { violin; died in 1759) }\end{array}$ & \\
\hline
\end{tabular}

55 The exact nature of the tasks carried out by Kapellknaben at the court of AnhaltZerbst remains unclear. It is likely that these young males were musically literate and played or sang (or both) with the orchestra on occasion and generally assisted with Kapelle-related duties. 


\begin{tabular}{|c|c|c|}
\hline Years & 1757 & 1763 \\
\hline & Johann Gottlieb Viepeck & Still active - died in 1767 \\
\hline $\begin{array}{l}\text { Court Kettle- } \\
\text { Drummer }\end{array}$ & $\begin{array}{l}\text { Johann Christian Wolland } \\
\text { (Volland, Vollund) (Marpurg: } \\
\text { violin) }\end{array}$ & Still active - died in 1767 \\
\hline \multirow{5}{*}{$\begin{array}{l}\text { Hautboisten }^{56} \\
\text { (Grenadiere) in } \\
\text { the palace guard }\end{array}$} & $\begin{array}{l}\text { Johann Christian Friedrich Ulrich } \\
\text { (oboe; violin?; died in 1761) }\end{array}$ & \\
\hline & $\begin{array}{l}\text { George Rudolph Kötteritz (oboe; } \\
\text { violin?) }\end{array}$ & Retired by 1762 \\
\hline & Hautboist Köppe (oboe; violin?) & Retired by 1762 \\
\hline & $\begin{array}{l}\text { Johann Friedrich Dalchör } \\
\text { (Dalchau) (oboe; violin?) }\end{array}$ & $\begin{array}{l}\text { Not listed in death registers, } \\
\text { possibly still active }\end{array}$ \\
\hline & $\begin{array}{l}\text { Johann Adolph Schröder (oboe; } \\
\text { violin?) }\end{array}$ & $\begin{array}{l}\text { Not listed in death registers, } \\
\text { possibly still active }\end{array}$ \\
\hline \multicolumn{3}{|l|}{$\begin{array}{l}\text { Additional } \\
\text { Personnel }\end{array}$} \\
\hline $\begin{array}{l}\text { Hofkirchner } \\
\text { (caretaker) }\end{array}$ & $\begin{array}{l}\text { Johann Peter Möhring (also viola } \\
\text { da gamba; violin) (Marpurg: violin } \\
\text { only) }\end{array}$ & [J. P.] Möhring \\
\hline Copyist & See Soprano and court organist & \\
\hline $\begin{array}{l}\text { Calcant (organ } \\
\text { bellows pumper) }\end{array}$ & (Johann?) Müller & Schöne [no first name known] \\
\hline
\end{tabular}

56 For a more detailed description of "Hautboisten" at the court of Anhalt-Zerbst see Barbara M. Reul, "Neuerkenntnisse zu Capellisten, Hautboisten und anderen im 18. Jahrhundert am Zerbster Hof tätigen Musikern," Fasch - Vater und Sohn, eds. Stadt Zerbst and Internationale Fasch-Gesellschaft e. V. Zerbst [Barbara M. Reul et al.], Fasch-Studien 11 (Beeskow: ortus-Verlag), forthcoming. 
Table 2: Compositional activities of J. G. Röllig and additional income -24 June 1762 and 23 June $1764^{57}$

\begin{tabular}{|c|c|c|c|}
\hline $\begin{array}{l}\text { Fiscal } \\
\text { Year }\end{array}$ & Compositions & $\begin{array}{c}\text { Total } \\
\text { income }\end{array}$ & $\begin{array}{l}\text { Increase } \\
\text { in salary }\end{array}$ \\
\hline $\begin{array}{l}1762 / \\
1763\end{array}$ & $\begin{array}{l}\text { 1) "Cantate" ["Lobet den Herren"] AND } \\
\text { 2) "Serenata" on the occasion of Friedrich August's } \\
\text { birthday [8 August 1762] } \\
\text { 3) "Cantata" AND } \\
\text { 4) "Serenata" on the occasion of the Catherine's } \\
\text { accession to the Russian throne [July 1763] } \\
\text { 5) "Cantata" and 6) "Serenata" for Catherine's } \\
\text { birthday [2 May 1763] } \\
\text { 7) } 13 \text { cantatas "missing" in Förster's yearly cantata } \\
\text { cycle } \\
\text { 8) "Passions Oratorium" [Music for Holy Week] } \\
\text { 9) New cycle [of sacred cantatas; } 30 \text { florins } \\
\text { advance] }\end{array}$ & $\begin{array}{c}325 \text { florins } \\
22 \text { Groschen }\end{array}$ & $+92 \%$ \\
\hline $\begin{array}{l}1763 / \\
1764\end{array}$ & $\begin{array}{l}\text { 1) New cycle of sacred cantatas [ } 112 \text { florins] } \\
\text { 2) "for [the same type of] musical composition on } \\
27 \text { August } 1763 \text { " (cantata and serenata on the } \\
\text { occasion of Friedrich August's birthday?) } \\
\text { 3) "... on } 15 \text { May } 1764 \text { " (cantata and serenata on } \\
\text { the occasion of Catherine's birthday) }\end{array}$ & $\begin{array}{l}310 \text { florins } \\
6 \text { Groschen }\end{array}$ & $+82 \%$ \\
\hline
\end{tabular}

57 See the respective entries in D-LHASA, DE, Z 92, Kammer Zerbst/Anhalt, Kammerrechnungen 1762/63, 245 and 1763/64, 254. 


\section{Figure 1. Beglückter Tag, movement 4, "Recitative" text ${ }^{58}$}

\author{
Erfreutes Volck, \\ das einst, wie aus der dicksten Finsterniß, \\ ein wahrer Vater seiner Staaten, \\ durch klugen Ernst und weises Rathen, \\ der Wuth der Barbarey entriß, \\ und das Elisabeth, die Große, \\ in süßer Ruhe sanfften Schooße, \\ mitt Macht beschützt, \\ mit Gnaden träncket, \\ die nie auf größre Thaten dencket, \\ als Ihren Ruhm in deinem Wohlergehn, \\ der Welt zum Wunder zu erhöhn. \\ Was kann dir denn in Catharinen, \\ die ihren Ursprung, als sie kam, \\ aus teutschen Heldenblute nahm, \\ zum Grunde der Verehrung dienen? \\ Was Millionen Seelen rühret, \\ und sie zum Freuden Opffer führet, \\ muß groß, erhaben, ungemein, \\ das muß beynah ein Wunder seyn.
}

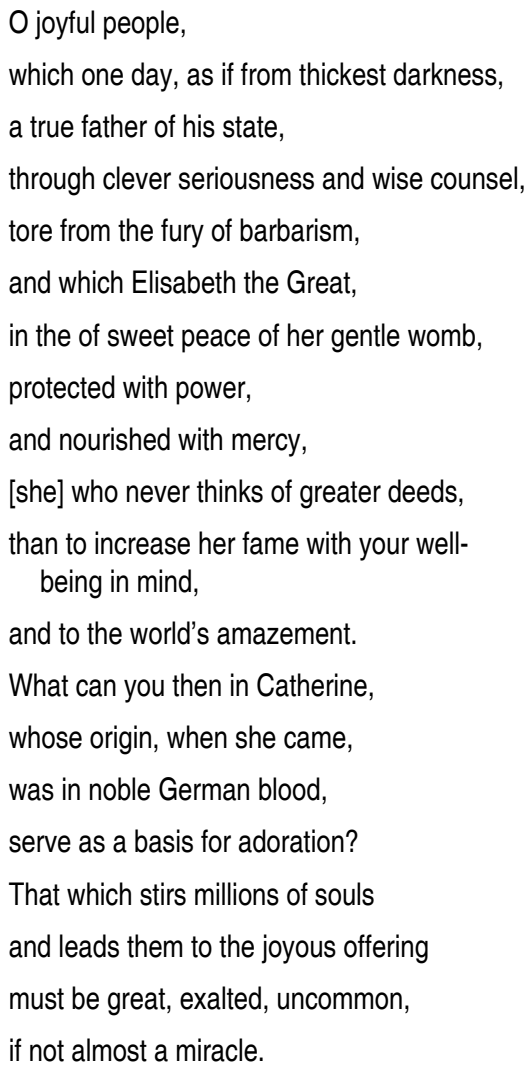


Figure 2. "Unterthänige Vorstellung" (Respectfully Submitted Proposal) by Johann Georg Röllig, 29 October 1762, D-LHASA, DE, Z 88, Facharchiv Zerbst Fach 12 Nr. 9, fol. 230r. Reproduced by permission

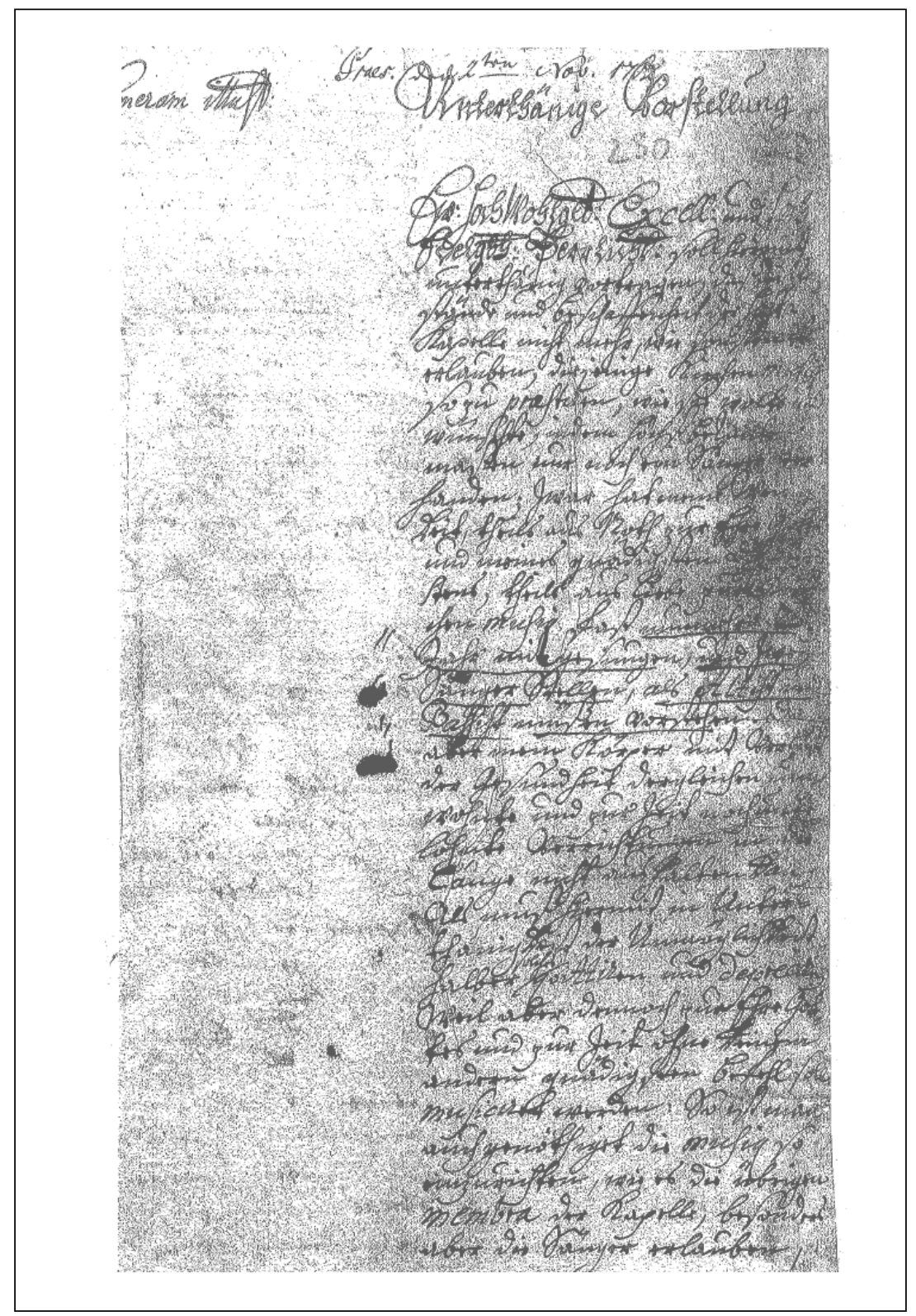

